\title{
Study regarding the main ways of gaining ball possession in Romanian basketball
}

\section{Dan IONESCU1 ${ }^{1}$, Mihai ALEXANDRU², Gabriela GUI-BACHNER ${ }^{3}$, Alin MOLCUȚ ${ }^{4}$}

\begin{abstract}
Introduction: In basketball, ball possession can begin and end in many different ways, for example, ball possession may begin with an out-of-bounds, a stolen ball, a rebound etc, and may also end with a throw, a turnover or when the attack time has expired. Aim: Starting from the working hypothesis that the backboard rebounds represent an important factor in gaining ball possession, we have proposed to identify and analyze the game parameters recorded in the national basketball leagues. Material and methods: The theoretical documentation included explaining, based on specialized literature, terms related to ball possession. Also, in order to accomplish the purposes of this research, we have used statistical analysis (possession, arithmetic mean, amplitude) and graphical representation. This study focused on all teams participating in the 2019-2020 season of the National Basketball Leagues (16 men's and 13 women's teams). Results: Following the analysis and centralization of the game parameters from the 146 games played in the men's league and 144 games in the women's league, we have identified the main ways of gaining ball possession.

Conclusions: Backboard rebounds represent the main way of gaining ball possession (which confirms the hypothesis).
\end{abstract}

Key words: Basketball, Ball Possession, Backboard rebounds

\section{Rezumat}

Introducere: În jocul de baschet posesia unei mingi poate începe și încheia în mai multe moduri diferite. De exemplu, posesia poate începe cu o repunere din out, cu o minge furată, cu o recuperare la panou etc. și de asemenea, se poate încheia cu o aruncare la coș, o minge pierdută sau la expirarea timpului de atac. Scop: Pornind de la ipoteza de lucru conform căreia urmăririle la panou reprezintă un factor important în intrarea în posesia mingii, ne-am propus să identificăm și să analizăm parametrii de joc înregistrați în ligile naționale de baschet. Material și metode: Documentarea teoretică a cuprins elucidarea din literature de specialitate a termenilor legați de posesia mingii. De asemenea, pentru îndeplinirea scopurilor acestei cercetări, am utilizat analize statistice (posesia, media aritmetică, amplitudinea) și reprezentarea grafică. Acest studiu s-a focusat asupra tuturor echipelor participante în sezonul 2019-2020 al ligilor naționale de baschet (16 echipe masculine și 13 feminine). Rezultate: În urma analizei și centralizării parametrilor de joc din cele 146 de partide desfășurate în liga de masculină și 144 de partide în liga feminină, a rezultat ordinea căilor de intrare în posesia mingii. Concluzii: Urmăririle la panou sunt principalele mijloace de intrare în posesia mingii.

Cuvinte cheie: Baschet, Posesia mingii,Urmăririle la panou

\footnotetext{
1 Lecturer PhD, "Politehnica" University Timișoara, Romania, e-mail: dan.ionescu@upt.ro

${ }^{2}$ Lecturer PhD, "Politehnica" University Timișoara, Romania, e-mail: mihai.alexandru@upt.ro

${ }^{3}$ Assistant Professor, PhD, "Politehnica" University Timișoara, Romania, e-mail: gabriela.gui-bachner@upt.ro

${ }^{4}$ Assistand Professor, PhD, "Politehnica" University Timișoara, Romania, e-mail: alin.molcut@upt.ro
} 


\section{Introduction}

The regulatory provisions on the reduction of the attack duration, but also the increase of the aggressiveness in the defense, have had the consequence of anincrease in the number of ball possessions. Ball possession can begin and end in many different ways [1], for example, ball possession may begin with an out-of-bounds or a won ball (steal or rebound) and may end with a throw, a turnover or when the attack time has expired.

Some authors [2] said that in basketball games, the percentage of successful shooting is to be about 50 $\%$ to $60 \%$ for two-point shots and about $30 \%$ to $35 \%$ for three-point shots. The remaining balls $40 \%$ to $50 \%$ of two-point shots and $65 \%$ to $70 \%$ of three-point shots - became rebounds [3].

\section{Aim and purpose of the study}

Starting from the working hypothesis [4] that the backboard rebounds represent an important factor in gaining ball possession, we have proposed to identify and analyze the game parameters recorded in the national men's (MNBL) and women's (WNBL) basketball leagues.

The purpose of this paper was to find out:

- to what extent the backboard rebounds provide the number of ball possessions and, implicitly, the number of attacks;

- to what extent the other parameters of the game (except backboard rebounds) influence the number of ball possessions;

Also, another purpose was to compare the game parameters obtained in the two leagues studied.

\section{Material and method}

The study has included the analysis of the following specialized terms:

- Ball possession - A statistic in basketball defined as the time a team gains offensive possession of the ball until it scores, loses the ball, or commits a violation or foul [5].

- Free throw - This is an unopposed shot that is taken at the free throw line [6].

- Field goal - In basketball, a field goal is a basket scored on any shot or tap other than a free throw, worth two or three points depending on the distance of the attempt from the basket [7].
- backboard rebound - In basketball, a rebound, sometimes colloquially referred to as a board, is a statistic awarded to a player who retrieves the ball after a missed field goal or free throw [8].

- Steal - A steal in basketball is when a defensive player is responsible for a legal turnover due to his/her positive, defensive actions [9].

- Turnover - a turnover occurs when a team loses possession of the ball to the opposing team before a player takes a shot at their team's basket [10].

Ball possession can be obtained in one of the following cases [11]:

- obtaining ball possession following a 1X1 engagement at the beginning of the first quarter;

- obtaining ball possession as a result of alternative possession;

- obtaining ball possession following a basket received during the game - Field goal received;

- obtaining ball possession following the registration of the last free throw from which the opposing team benefited;

- obtaining ball possession following the intervention on the opponent dribble or the passing line, the snatching of the ball from the opponent's arms (steal) or following the blocking of an opponent's shot;

- obtaining ball possession following a defensive rebound (during the game or after the execution of the last free throw from which the opposing team benefited);

- obtaining ball possession following a violation of the rules committed by the opposing team Turnover (Traveling; double dribble; violations of the rules of $3,5,8$, and 24 seconds; bad pass, out of bounds; offensive foul etc.).

In order to achieve the purpose of the research, the following methods have been used:

- Statistical and mathematical calculation Ball possessions

Ball possessions were calculated with the following equations [12]:

$$
\text { Possession }=\mathrm{FGA}+0.44 \times \mathrm{FTA}+\mathrm{TO}
$$

where FGA is the number of field goal attempts, FTA is the number of free throw attempts and TO is the number of turnovers. 


\section{Arithmetic mean}

It represents the resulted mean from the assembly of the each value of the variable related to a total. Amplitude

The amplitude is the differences between the maximum and minimum value [14].

Amplitude $=X_{\text {max }}-X_{\text {min }}$

- Graphical representation

This study focused on all participating teams in the 2019-2020 season of the National Basketball Leagues (16 men's and 13 women's teams), totaling 290 games. The statistics of each team were analyzed [15] and the main parameters leading to the number of cases (the sum of the individual values_divided by the number of cases) [13].

The changes of ball possession were centralized opponent field goals, total team rebounds and opponent turnover.

\section{Results}

The following data were generated by the deployment, analysis and centralization of the 146 games played in the men's league and the 144 games in the women's league:

\begin{tabular}{cccccc}
\hline No. & Men`s NBL Team & $\begin{array}{c}\text { Opp } \\
\text { F G }\end{array}$ & $\begin{array}{c}\text { Total } \\
\text { Reb }\end{array}$ & $\begin{array}{c}\text { Opp } \\
\text { To }\end{array}$ & $\begin{array}{c}\text { Team } \\
\text { Ball Poss }\end{array}$ \\
\hline 1 & UBT CLUJ NAPOCA & 27,2 & 37,3 & 14,5 & 85,36 \\
\hline 2 & CSM ORADEA & 26,1 & 35,1 & 14,4 & 81,68 \\
\hline 3 & CSU SIBIU & 26,2 & 40,7 & 13,7 & 88,02 \\
\hline 4 & DINAMO BUCUREȘTI & 30,3 & 32,5 & 13,2 & 83,96 \\
\hline 5 & STEAUA BUCUREȘTI & 31,5 & 35,1 & 10,6 & 83,39 \\
\hline 6 & CSM TIMIȘOARA & 31,1 & 32,8 & 12,4 & 83,44 \\
\hline 7 & BCMU PITEȘTI & 30,2 & 36,4 & 15,1 & 87,64 \\
\hline 8 & SCMU CRAIOVA & 28,2 & 34,0 & 14,0 & 84,21 \\
\hline 9 & CSO VOLUNTARI & 27,1 & 37,1 & 15,5 & 84,64 \\
\hline 10 & CSM GALAȚI & 26,4 & 38,0 & 15,9 & 87,08 \\
\hline 11 & CSM MEDIAȘ & 30,6 & 37,5 & 12,6 & 85,92 \\
\hline 12 & CSM FOCȘANI & 29,7 & 39,9 & 13,7 & 88,34 \\
\hline 13 & ATHLETIC & 26,7 & 39,2 & 16,2 & 87,96 \\
& CONSTANȚA & & & & \\
\hline 14 & CSM TÂRGU JIU & 30,1 & 36,0 & 12,5 & 84,79 \\
\hline 15 & CSM MIERCUREA CIUC & 31,4 & 35,5 & 15,4 & 87,67 \\
\hline 16 & CSM SIGHETU M. & 34,5 & 34,6 & 13,4 & 88,14 \\
\hline \multicolumn{7}{c}{ Average } & $\mathbf{2 9 , 2 0}$ & $\mathbf{3 6 , 3 5}$ & $\mathbf{1 3 , 9 4}$ & $\mathbf{8 5 , 7 6}$ \\
\hline & Amplitude & $\mathbf{8 , 4}$ & $\mathbf{8 , 2}$ & $\mathbf{5 , 6}$ & $\mathbf{6 , 6 6}$ \\
\hline
\end{tabular}

Table I. Game parameters in the Romanian Men's NBL (the teams are ordered by season ranking) 
In the men's league (Table I) it can be noticed that for all the studied teams, regardless of the position in the ranking, the order of the ways of gaining ball possession is the same.

Thus, the first place is occupied by backboard rebounds, seconded by ball possessions following the goals received, and the third place is taken by ball possessions due to the opponent's turnovers.

In the women's league, the order of the main ways of gaining ball possession remains unchanged (Table II).

\begin{tabular}{cccccc}
\hline No. & Women`s NBL Team & $\begin{array}{c}\text { Opp } \\
\text { F G }\end{array}$ & $\begin{array}{c}\text { Total } \\
\text { Reb }\end{array}$ & $\begin{array}{c}\text { Opp } \\
\text { To }\end{array}$ & $\begin{array}{c}\text { Team } \\
\text { Ball } \\
\text { Poss }\end{array}$ \\
\hline 1 & SEPSI SF GHEORGHE & 19,2 & 47,9 & 23,1 & 97,89 \\
\hline 2 & CSM SATU MARE & 21,0 & 39,5 & 17,7 & 83,63 \\
\hline 3 & FCC BASCHET ARAD & 19,5 & 39,7 & 19,8 & 84,14 \\
\hline 4 & CSM TÂRGOVIȘTE & 24,7 & 40,5 & 16,3 & 86,17 \\
\hline 5 & OLIMPIA BRAȘOV & 28,1 & 38,3 & 17,1 & 88,38 \\
\hline 6 & U CLUJ NAPOCA & 26,0 & 38,2 & 18,0 & 87,74 \\
\hline 7 & ACS KSE TG. & 22,2 & 41,8 & 20,4 & 89,55 \\
\multicolumn{7}{c}{ SECUIESC } & & & & \\
\hline 8 & PHOENIX & 25,5 & 42,0 & 19,6 & 90,43 \\
& CONSTANȚA & & & & \\
\hline 9 & CSM ALEXANDRIA & 24,3 & 38,5 & 23,2 & 91,19 \\
\hline 10 & BC SIRIUS TG. MUREȘ & 25,7 & 35,9 & 17,7 & 88,69 \\
\hline 11 & RAPID BUCUREȘTI & 27,0 & 38,8 & 21,6 & 92,07 \\
\hline 12 & AGRONOMIA & 25,2 & 45,9 & 16,8 & 94,09 \\
& BUCUREȘTI & & & & \\
\hline 13 & ROOKIES ORADEA & 29,7 & 32,2 & 21,0 & 88,03 \\
\hline \multicolumn{7}{c}{ Average } & $\mathbf{2 4 , 4 6}$ & $\mathbf{3 9 , 9 3}$ & $\mathbf{1 9 , 4 0}$ & $\mathbf{8 9 , 3 8}$ \\
\hline Amplitude & $\mathbf{1 0 , 5}$ & $\mathbf{1 5 , 7}$ & $\mathbf{6 , 9}$ & $\mathbf{1 4 , 2 6}$ \\
\hline
\end{tabular}

Table II. Game parameters in the Romanian Women's NBL

(the teams are ordered by season ranking)

Comparing the values of the parameters resulted in the 2 leagues (Fig. 1), we can see that in the women's league there are more ball possessions than in the men's league, most of the difference resulting from the number of opponent turnovers, which can raise questions about the technical quality of the players. Also, another parameter from which the total number of ball possessions derives, is the number of goals (baskets) received - lower in the women's league than in the men's league, the result of this being the difference in backboard rebounds.

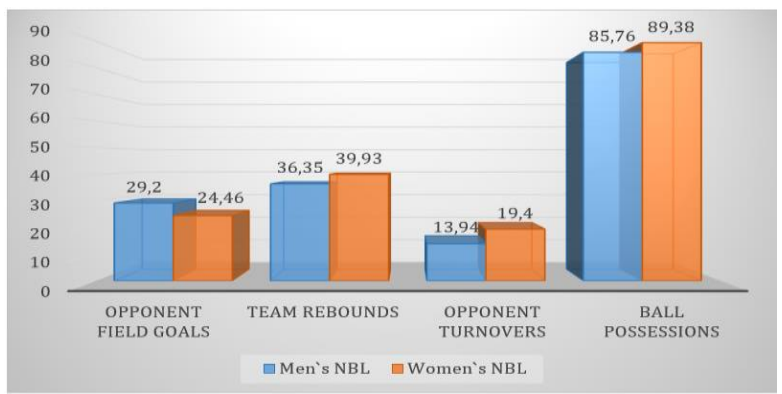

Figure 1. The average of the parameters obtained in the National Basketball Leagues

All these aspects, related to the total number of ball possessions, give us the percentage of the ways of gaining ball possession in the two leagues studied (Fig. 2).

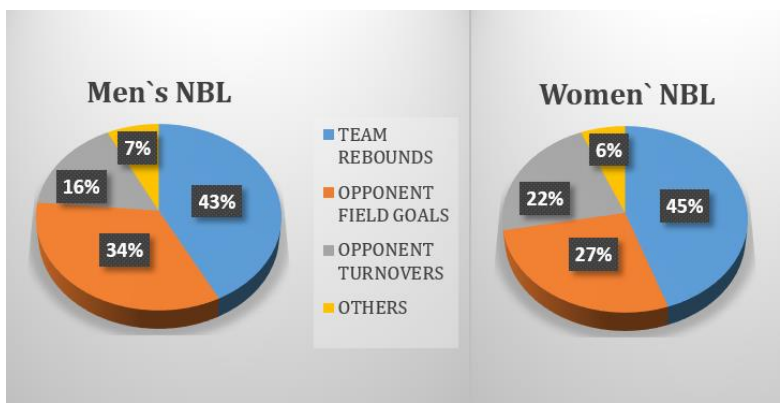

Figure 2. Ways of gaining ball possession

Regarding the amplitude of the game parameters studied in the 2 leagues (Table III), we can see that, in the women's league, higher values were obtained for all indices analyzed, one explanation being the lack of value homogeneity of the participating teams.

\begin{tabular}{ccccccc}
\hline & \multicolumn{3}{c}{ Men`s NBL Team } & \multicolumn{3}{c}{ Women`s NBL Team } \\
\cline { 2 - 7 } & Max & Min & \multicolumn{2}{c}{ Amplitude } & Max & Min \\
\hline $\begin{array}{c}\text { Opponent } \\
\text { Field Goals }\end{array}$ & 34,5 & 26,1 & 8,4 & 10,5 & 29,7 & 19,2 \\
\hline $\begin{array}{c}\text { Team Total } \\
\text { Rebounds }\end{array}$ & 40,7 & 32,5 & 8,2 & 15,7 & 47,9 & 32,2 \\
\hline $\begin{array}{c}\text { Opponent } \\
\text { Turnovers }\end{array}$ & 16,2 & 10,6 & 5,6 & 6,9 & 23,2 & 16,3 \\
\hline $\begin{array}{c}\text { Team Ball } \\
\text { Possessions }\end{array}$ & 88,34 & 81,6 & 6,66 & 14,26 & 97,89 & 83,67 \\
\hline
\end{tabular}

Table III. Amplitude comparison

\section{Discussions}

Defensive rebounds are indicators of good team defense. The goal of good defense is to prevent offensive players from shooting freely without defense, and from the position where they are shooting at a high percentage, and then, to box out and prevent offensive players from taking the ball. 
This increases the number of unsuccessful shots, and the chance for a defensive rebound. Teams that have more rebounds in defense have more chances for fastbreaks [16]. Several previous studies [17], [18] confirm the importance of backboard rebounds, regardless of the level of competition or gender of the players, which makes the difference between a winning team and a losing team.

Our study fails to demonstrate the validity of these facts, because, as it can be seen from the study of the game parameters resulting in both competitions, top 3 also includes teams from the bottom of the standings, with a small number of victories.

\section{Conclusions}

As a result of our study, we can draw the following conclusions:

- Backboard rebounds represent the main way of gaining ball possession (which confirms the hypothesis);

- In the studied national leagues, for all participating teams, regardless of the place in the standings, the order of the ways of gaining ball possession is kept unchanged;

- The share of the ways of gaining ball possession is different in men's basketball, compared to women's basketball, due to the existing technical and psychomotor particularities.

\section{References}

1. Stanćin I. (2018). Dubinska analiza statističkih kategorija praćenja igrača u košarkaškim ekipama, Diplomski Rad br. 1577, Fakultet Elektrotehnike I Računarstva, Zagreb, 1

2. Yoshii S., (1994). Basketball I belive, Taishukan - Shoten: Tokio, 290 - 320.

3. Komure I., Aoyagi O., Sakuragi K., Tagata S. (2014) Relationship between offensive and defensive rebounds and the outcome of games : analysis of rebounds data from the standpoint of counts, differences and ratios, Fukuoka University, Volume 45, issue 1, 1-8

4. Chelcea S. (2001). Metodologia cercetării sociologice. Metode cantitative și calitative, Editura Economică, 78.

5. https://www.sportingcharts.com/dictionary/nba/possessi on.aspx Retrieved April 23, 2020

6. https://www.sportslingo.com/sports-glossary/f/freethrow/ Retrieved April 23, 2020

7. https://en.wikipedia.org/wiki/Field goal (basketball) Retrieved April 23, 2020

8. https://en.wikipedia.org/wiki/Rebound (basketball) Retrieved April23, 2020

9. https://www.sportslingo.com/sports-glossary/s/stealbasketball/ Retrieved April 23, 2020
10. https://en.wikipedia.org/wiki/Turnover_(basketball) Retrieved April 23, 2020

11. Selmanović A. (2015). Comparison of the structure of offense in the european and american basketball, Doctoral Thesis, Faculty of Kinesiology, Zagreb, 24

12. https://sports.stackexchange.com/questions/20472/posse ssion-in-basketball Retrieved May 07,2020

13. Popa G. (1999). Metodologia cercetării științifice în domeniul educației fizice și sportului, Editura Orizonturi Universitare, Timișoara, 125

14. Clocotici V., Stan A., (2001). Statistică aplicată în psihologie, Editura Polirom, Iași, 64

15. https://www.frbaschet.ro/baschet/team?teamId=21842\&s easonId=111397 Retrieved May 05,2020

16. Mikić M., Vučković I., Karać A., Belegišanin B., Vukićević V., Stojanović M. (2018). Game related statistics that discriminated winning and losing teams in the nlb league, University of Niš, Facta Universitatis Series: Physical Education and Sport, 16 (2), 477 - 486

17. Sampaio J., Janeira M. (2003). Statistical analyses of basketball team performance: Understanding teams' wins and losses according to a different index of ball possessions. International Journal of Performance Analysis in Sport, 3, 40-49.

18. Gómez M. A., Lorenzo A., Sampaio J., Ibáñez S. J., Ortega E. (2008). Game-related statistics that discriminated winning and losing teams from the Spanish men's professional basketball teams, Collegium Antropologicum, 32(2), 315319. 